\title{
A New Vocabulary
}

\author{
GABRIELE LAZZARI
}

A lthough the history of humanity is arguably the history of its global peregrinations, at no other time than today has migration so profoundly shaped our political imaginary and public discourse. As Achille Mbembe has written, "The government of human mobility might well be the most important problem to confront the world during the first half of the 2Ist century." 1 On the one hand, human mobility and any attempt to regulate it depend on geopolitical variables, economic calculations, and international treaties. On the other, migration is an experience that requires, both for displaced groups and for host communities, a constant effort to reimagine social relations, affective investments, and modes of belonging. In this context, literature has the peculiar ability to register the entanglements of collective histories and political conditions with the individualized experience of migrants, often challenging the ethnonationalist discourses that pervade today's mediascape.

Three recent essays on this topic-Nasia Anam's "The Migrant as Colonist: Dystopia and Apocalypse in the Literature of Mass Migration," Marissia Fragkou's "Strange Homelands: Encountering the Migrant on the Contemporary Greek Stage," and Dominic Thomas's "The Aesthetics of Migration, Relationality, and the Sentimography of Globality" - powerfully show how current aesthetic practices that engage migration provide us with a new vocabulary, necessary to restore the figure of the migrant to his or her fullness and complexity as an individual. Interestingly, Anam's article begins by analyzing literature that tries to do the opposite, that is, works of fiction that cast migrants as hordes of invading barbarians. She focuses on recent examples of Anglophone and French fiction that, in figuring migration as an apocalyptic event that threatens to destroy European civilization, epitomize Europe's transition from an outward-looking "colonial utopianism," with its attendant myth of mission civilisatrice, to current nationalisms that cast the continent as a colonized victim of mass migration. ${ }^{2}$ This is the same ideological shift that has been analyzed in the US context, where the myth of the frontier and imperialist expansion has given way to that of the border, with its racialized and classed rhetoric of self-protection.

Amid such a hostile political and cultural climate, works of imaginative literature can respond in two ways. The first is to frame migrants as absolutely innocent subjects in desperate need of First World help. This attitude is meant to elicit a kind 
of philanthropic empathy, which deprives migrants of psychological complexity and disregards the historical and economic causes of migration. One can see its consequences on the legislative level, particularly in the problematic distinction and consequent hierarchization among the categories of refugee, asylum seeker, and economic migrant-which, as Thomas rightly points out, "transfer accountability, obligations, and responsibility away from organizations that enact [these policies] onto those targeted by the ensuing decrees and legislation." ${ }^{3}$

The other option, which is not as easily practicable as it might sound, is to let migrants speak for themselves. In doing so, we might be able to undo categories and structures of feeling that have been naturalized and left unquestioned for decades. Both Anam and Fragkou analyze examples in fiction and theater where "the exilic subject [finds] a space for resignification," thus shifting the conversation from dystopian and apocalyptic scenarios or threats to the integrity of the nation-state to the possibility of foregrounding "the subjectivity of the migrant [as] one of infinite elasticity and adaptability." 4 This endeavor seems particularly relevant in the European South, where the worst economic recession of the postwar era and the eruption of long-repressed nativist fantasies have led to identifying in the migrant the scapegoat for any social issue affecting southern European nations. Fragkou's discussion focuses on Greece, and particularly on plays that challenge this kind of collective neurosis. In the works she discusses, migrants are authors and actors, they bring their native languages onstage, and-most important-they respond to ethnic, gender, and class stereotypes by playfully reversing their premises. The situation of Greece as discussed by Fragkou is not dissimilar from what has been happening in other southern European countries, which, because of their geographic position, have experienced a massive influx of migrants and have thus started to rethink the foundational principles of national belonging. This is the case in Italy, where, in recent years, the fictional and nonfictional production of a group of first- and second-generation immigrants has questioned the supposed racial and cultural homogeneity of the nation, envisioning instead, just as in the Greek examples discussed by Fragkou, "heteroglossic . . . understandings of national identity."

The three essays thus demonstrate that aesthetic practices encourage us to imagine different and more nuanced ways of discussing global migration. Yet they also suggest that without a serious engagement with the histories of oppression and economic unevenness that continue to force people to flee their homes to seek a better future, any attempt to engage migration, however well meant, can fall back into a philanthropic gaze that ignores subject positions and power imbalances. In other words, empathy is not enough. Thomas's article stresses how works of art can foster "meaningful relationality and therefore symmetry." 6 This approach, however, risks downplaying the historical genealogies of migration as well as the fact that symmetrical relationality seems hard to achieve without social and economic equality.

Instead, what works of fiction can do is push for a more serious engagement with migration beyond binary divisions into native and migrant or citizen and foreign, while drawing attention to the power dynamics involved in any act of representation. If this growing body of aesthetic production and criticism addressing migration will 
be able to steer the conversation away from the vocabulary of crisis and emergency, we might finally begin to envision concrete and more just modes of community building and social participation—on the local, national, and global scales.

GABRIELE LAZZARI is a PhD candidate in comparative literature at Rutgers University. His dissertation proposes a new paradigm — premised on four spatial concepts: scale, border, semiperiphery, and world—for the analysis of contemporary fiction.

Notes

Mbembe, "Scrap the Borders."

Anam, "The Migrant as Colonist," 655.

Thomas, "Aesthetics of Migration," I66.

Fragkou, "Strange Homelands," 307; Anam,

"The Migrant as Colonist," 676.

5 Fragkou, "Strange Homelands," 304.

6 Thomas, "Aesthetics of Migration," I7I.

\section{Works Cited}

Anam, Nasia. "The Migrant as Colonist: Dystopia and Apocalypse in the Literature of Mass Migration." ASAP/Journal 3, no. 3 (2018): 65377. muse.jhu.edu/article/71ı837. doi. org/10.1353/asa.2018.0043.
Fragkou, Marissia. “Strange Homelands: Encountering the Migrant on the Contemporary Greek Stage." Modern Drama 6I, no. 3 (20I8): 30I-27. moderndrama .utpjournals.press/doi/I0.3138/md.so919.3. doi.org/I0.3138/md.so919.3.

Mbembe, Achille. "Scrap the Borders That Divide Africans." Mail and Guardian, March I7, 2017. mg.co.za/article/20I7-03-I7-oo-scrap-the -borders-that-divide-africans.

Thomas, Dominic. "The Aesthetics of Migration, Relationality, and the Sentimography of Globality." L'esprit créateur 59, no. 2 (2019): I65-79. muse.jhu.edu/article/728229. doi. org/10.1353/esp.2019.0023. 